\title{
Digital Media Marketing Strategies for MSMEs during the Covid-19 Pandemic
}

\author{
Strategi Pemasaran Media Digital bagi UMKM di Masa Pandemi \\ Covid-19
}

Abstract

Covid-19 pandemic has changed marketing patterns of the Micro, Small, and Medium Enterprises (MSMEs) entrepreneurs to allow them to survive adversities as the impact of public activity restrictions by the government. The decline in consumer intensity and flow

of goods and services has caused the reduction of entrepreneurs' income as well as the goods and services trade cycle. This condition then encourages the entrepreneurs to adopt digital technology and develop digital entrepreneurship. The employment of digital technology and combination of knowledge, creativity, and innovation are crucial to ensure the survival of MSMEs during this pandemic. Government support in the forms of assistance, training, and program support for the digitalization of MSMEs continue to do

considering they are the most impacted sector. The government through its several agencies keep working together to make entrepreneurs familiar with digital marketing. This research uses qualitative approach with library research as its method combined with interviews with the MSMEs entrepreneurs. This research found that the MSMEs entrepreneurs need to adopt digital technology in the forms of digital entrepreneurship transformation, digital marketing and creativity, and innovation in order to survive during the Covid-19 pandemic.

\section{Anindita Trinura Novitasari STKIP PGRI Bangkalan Jl. Sukarno Hatta No.52} aninditatrinura2015@stkippgri-bkl.ac.id
Keywords: adoption, transformation, digital marketing

\section{DOI}

https://doi.org/10.37010/fcs.v2i1.348

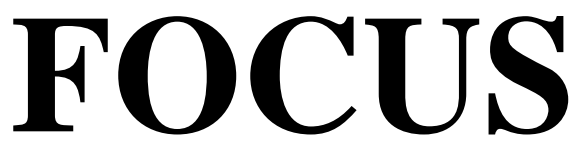

\section{Journal of Social Studies}

\section{Vol. 2 No. 2 AGUSTUS} 2021

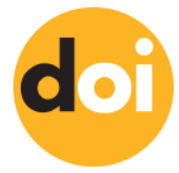

Abstrak

Pandemi Covid-19 merubah pola pemasaran pelaku usaha UMKM untuk bertahan ditengah kesulitan yang dialami UMKM menghadapi dampak dari pemberlakuan peraturan pemerintah dalam tanggap penanggulangan Covid-19. Intensitas konsumen, arus barang dan jasa yang mengalami penurunan mengakibatkan pengurangan dari sisi pendapatan pelaku usaha serta penurunan arus perputaran barang dan jasa yang diperjualbelikan. Kondisi ini kemudian mulai mengajak pelaku usaha untuk mengadospsi teknologi digital dalam transformasi kewirausahaan menjadi kewirausahaan digital. Pemanfaatan teknologi digital, perpaduan pengetahuan dan kreativitas serta inovasi pelaku usaha dibutuhkan untuk keberlangsungan UMKM bertahan di masa pandemi

ini. Dukungan pemerintah dalam pendampingan, pelatihan, dan dukungan program menyukseskan digitalisasi UMKM terus digalakkan sejak UMKM menjadi sektor terdampak pandemi Covid-19. Pemerintah melalui beberapa instansi terkait terus menggalakkan koordinasi untuk mempersiapkan pelaku usaha yang familiar dengan pemasaran digital. Metode penelitian ini dilakukan dengan metode kualitatif melalui kajian literatur diikuti dengan wawwancara objek penelitian pelaku usaha UMKM. Hasil penelitian memperoleh temuan

bahwa pelaku usaha UMKM dalam pemasaran produknya perlu adanya tindakan adopsi teknologi digital dalam bentuk transformasi kewirausahaan digital, pemasaran digital, dan kreativitas serta inovasi pemasaran digital untuk bertahan ditengah pandemi Covid-19.

Kata kunci: adopsi, transformasi, pemasaran digital 


\section{PENDAHULUAN}

Satu tahun lebih sudah pandemi Covid-19 berada di sekitar kita sejak 2 Maret 2020 terdeteksi masuk ke Indonesia dan hingga saat ini belum menunjukkan tanda-tanda berakhir. Tentang awal penyebaran virus corona ini disampaikan dalam penelitian Rosita,R (2020) pandemi Covid-19 di Indonesia pertama kali dideteksi pada 2 Maret 2020, saat itu diketahui 2 WNI terkonfirmasi tertular virus corona dari seorang warga negara Jepang. Setelah konfirmasi ini penyebaran virus terjadi cepat. Pada 9 April diketahui pandemi telah tersebar ke 34 provinsi dengan terdeteksi Jawa Timur, DKI Jakarta, dan Sulawesi Selatan sebagai provinsi yang paling terpapar.

Upaya mensosialisasikan pencegahan dan pemutusan mata rantai virus ini dilakukan pemerintah pada masyarakat mulai dari physical Distancing, Work From Home (WFH) bagi dunia kerja dan dunia pendidikan hingga anjuran pemerintah dengan diberlakukannya Pembatasan Sosial Berskala Besar (PSBB). Saat ini kita sedang berada pada upaya pemerintah dalam pemberlakuan Pembatasan Sosial berskala Besar (PSBB) Darurat karena bangsa ini tengah berada pada masa di mana penyebaran virus Covid-19 telah banyak menumbangkan masyarakat kita dan menambah jumlah angka kematian yang disebabkan oleh penyebaran wabah virus corona.

UMKM memiliki kontribusi besar dalam perekonomian khususnya perluasan penyerapan tenaga kerja. UMKM memberikan manfaat dalam peningkatan ekonomi masyarakat berpenghasilan rendah melalui ekonomi produktif di samping itu UMKM juga memiliki kontribusi dalam peningkatan PDB (Pendapatan Domestik Bruto). Peran UMKM dalam perekonomian disampaikan dalam penelitian Kristiyanti,M (2012) UMKM memiliki peran yang strategis dalam pembangunan ekonomi nasional oleh karena selain berperan dalam pertumbuhan ekonomi dan penyerapan tenaga kerja juga berperan dalam pendistribusian hasil-hasil pembangunan. Hal senada tentang peran UMKM dalam perekonomian disampaikan dalam penelitian Sarfiah,S et al (2019) posisi UMKM dalam perekonomian nasional memiliki peran yang penting dan strategis. Eksistensi UMKM cukup dominan dalam perekonomian Indonesia. Hal ini dapat terlihat dari jumlah industri yang besar dan terdapat dalam setiap sektor ekonomi, potensi yang besar dalam penyerapan tenaga kerja, dan kontribusi UMKM dalam pembentukan Produk Domestik Bruto (PDB) sangat dominan.

Pandemi Covid-19 telah memberikan dampak pada semua sektor kehidupan, UMKM pun menjadi sektor yang terdampak akibat pandemi ini. Penerapan PSBB telah memberikan dampak pada kelangsungan pelaku usaha UMKM dikarenakan adanya pembatasan interaksi antar individu hal ini akan berdampak pada pembatasan interaksi secara langsung antara produsen dan konsumen. Perubahan kinerja UMKM dikarenakan adanya dampak pandemi ini tersampaikan dalam penelitian yang dilakukan oleh Pakpahan,A (n.d) kajian yang dibuat oleh kementerian keuangan menunjukkan bahwa pandemi Covid-19 memberikan implikasi negatif bagi perekonomian domestik seperti penurunan konsumsi dan daya beli masyarakat, penurunan kinerja perusahaan, ancaman pada sektor perbankan dan keuangan, serta eksistensi UMKM. Penurunan daya beli konsumen dimasa pandemi Covid19 disampaikan dalam penelitian yang dilakukan oleh Arianto,B (2020) harus diakui bahwa pandemi Covid-19 menyebabkan menurunnya daya beli masyarakat. Dikarenakan publik telah mengurangi interaksi di luar ruangan untuk menekan persebaran pandemi. Banyak konsumen yang kemudian menjaga jarak dan kemudian mengalihkan pembelian secara digital. Dampaknya, banyak UMKM yang harus menutup usahanya karena menurunnya pembelian dan masih bergantung pada penjualan secara luar jaringan.

Perubahan metode penjualan yang awalnya bisa melakukan penjualan secara langsung saat ini pelaku usaha dituntut untuk mampu memadukan kemampuan dan keterampilannya untuk menciptakan metode pemasaran secara online dan offline. Tidak bisa dihindari sektor penjualan kemudian berubah haluan menjadi penjualan secara online. Ketika sudah berada pada paradigma penjualan produk secara online maka pelaku usaha dituntut familiar dengan metode pemasaran menggunakan teknologi digital. Mengingat kondisi pandemi ini yang mengharuskan semua serba menggunakan teknologi informasi dalam berbagai sektor kehidupan dikarenakan pembatasan interaksi antar individu untuk memutus mata rantai penyebaran virus corona. Penggunaan teknologi digital dalam pemenuhan kebutuhan disampaikan dalam penelitian yang dilakukan Rosita, $R$ (2020) tak dapat dipungkiri, perlakuan semua sudah beralih ke arah digital. Interaksi antara manusia dan teknologi tidak dapat dielakkan lagi. Semua pemenuhan kebutuhan sudah tersedia secara digital, mulai dari jual beli, jasa, hingga transaksi pembayaran. 


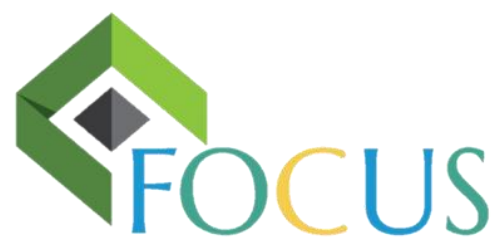

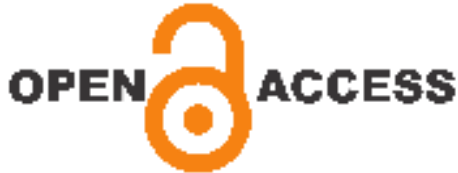

Kondisi di masa pandemi ini semua sektor kehidupan menuntut setiap individu mulai membiasakan diri dengan penggunaan teknologi digital. Penggunaan teknologi digital kemudian menjadi syarat mutlak dalam menyelaraskan roda perekonomian di masa pandemi. Hal ini disampaikan dalam penelitian yang dilakukan oleh Arifqi,M \& Junaedi,D (2021) kegiatan UMKM pada kondisi pandemi Covid-19 ini memberikan tantangan sekaligus peluang bagi perkembangan perekonomian Indonesia. Adapun tambahan yang dimaksud yaitu perlu adanya solusi jangka pendek untuk membantu para stakeholder atau pelaku UMKM agar tetap berjalan maksimal dengan berbagai keterbatasan kebijakan pemerintah. Sedangkan peluangnya dapat diartikan sebagai sebuah proyek pemerintah untuk merancang aktivitas perekonomian UMKM secara mudah dengan menyesuaikan pada perkembangan teknologi. Indonesia yang juga berada pada era industri secara tidak langsung menuntut bentuk aktivitas perekonomian masyarakat berbasiskan pada teknologi atau dikenal dengan istilah digitalisasi UMKM. Hal senada mengenai penggunaan teknologi digital dalam dunia UMKM di masa pandemi ini perlu disertakan dukungan beberapa pihak terkait untuk membiasakan UMKM dengan penggunaan teknologi digital agar mampu terus bertahan disampaikan dalam penelitian Nalini, S (2021) para pekerja UMKM perlu beradaptasi dengan penggunaan teknologi produksi baru dan teknologi digital, pembangunan infrastruktur telekomunikasi dan program internet masuk desa, pelibatan dunia akademisi dan usaha besar dalam pendampingan pengenalan dan penggunaan teknologi produksi dan media digital, serta menghidupkan kembali program kemitraan usaha besar dan UMKM.

Penggunaan teknologi digital dari beberapa data yang diperoleh selama masa pandemi Covid-19 melalui penggunaan platform media sosial terus mengalami peningkatan dan mengalami korelasi dengan transaksi penjualan UMKM. Pada era pandemi ini, pelaku usaha yang berhasil bertahan adalah pelaku usaha yang dapat memanfaatkan platform digital dan media sosial. Eksistensi dari pelaku usaha selama mas pandemi dengan penggunaan platform ditunjukkan dalam pernyataan yang disampaikan Purwana et al dalam Arianto,B (2020) penggunaan platform digital oleh pelaku UMKM di Indonesia cukup meningkat. Terdapat 42 persen UMKM Indonesia yang sudah menggunakan media sosial. Dengan kata lain media sosial merupakan sarana pengembangan kewirausahaan dalam keberlangsungannya di tengah pandemi ini. Penggunaan media digital dalam pemasaran juga disampaikan dalam penelitian Dijayanti,A \& Pramesti,P (2021) hampir semua kebutuhan masyarakat dipenuhi dengan berbelanja menggunakan digital e-commerce atau online. Hingga kini transaksi E-commerce masih mendominasi di Indonesia. Banyaknya pengguna mesin pencari seperti Google, situs e-commerce, dan sosial media bisa dijadikan peluang pemasaran yang baik dalam penggunaan pemasaran produk yang diinginkan.

\section{METODE}

Metode penelitian ini menggunakan metode penelitian kualitatif. Prosedur pelaksanaannya dengan mengkaji beberapa referensi yang relevan dan memiliki keterkaitan dengan konteks yang dibahas dalam penelitian ini, yakni mengenai strategi pemasaran digital pada UMKM dalam menyikapi situasi pandemi yang memberikan dampak pada proses penjualan secara langsung untuk keberlanjutan pelaku usaha UMKM. Ada beberapa bahan penelitian yang diperoleh melalui:

1. Studi kepustakaan dilakukan dengan pengumpulan data yang menggunakan metodologi studi pustaka. Penulis dalam hal ini mencari dan mengumpulkan berbagai informasi dan keterangan yang dibutuhkan dari berbagai media berupa buku, jurnal, prosiding dan artikel sebagai pendukung tersusunnya artikel ini.

2. Wawancara, dilakukan untuk mencari dan mengumpulkan informasi dari beberapa responden pelaku usaha UMKM mengenai berbagai informasi dan keterangan yang berkaitan dengan kelangsungan usaha yang dijalankan selama bertahan dimasa pandemi.

3. Melalui hasil wawancara dan dipadukan dengan sistematika literatur yang diperoleh mengenai bahasan penelitian kemudian ditarik temuan yang diperoleh sebagai novelty penelitian untuk menjawab permasalahan yang diangkat dalam penelitian ini. 


\section{HASIL DAN PEMBAHASAN}

\section{Kewirausahaan Digital}

Kewirausahaan diartikan sebagai proses di mana seseorang dapat memanfaatkan peluang yang ada dalam sumber daya yang terbatas. Pemenuhan sumber daya dalam berwirausaha menyertakan daya berpikir kreatif dan inovatif sebagai kiat dalam menghadapi tantangan hidup (Agustina,T, 2015). Kewirausahaan selalu di sama artikan dengan Usaha Mikro Kecil Menengah (UMKM). Berdasarkan UU UMKM No.20 Tahun 2008 kriteria masingmasing skala usaha yang diatur dalam pasal 6. Kriteria usaha mikro memiliki kekayaan bersih paling banyak Rp50.000.000 tidak termasuk tanah bangunan tempat usaha. Hasil penjualan tahunan paling banyak Rp300.000.000. Kriteria usaha kecil memiliki kekayaan bersih lebih dari Rp 50.000.000,00 sampai dengan paling banyak Rp500.000.000 tidak termasuk tanah dan bangunan tempat usaha. Memiliki hasil penjualan tahunan lebih dari Rp300.000.000 sampai dengan paling banyak Rp2.500.000.000. Kriteria usaha menengah memiliki kekayaan bersih lebih dari Rp500.000.000 sampai dengan paling banyak Rp10.000.000 tidak termasuk tanah dan bangunan tempat usah. Memiliki hasil penjualan tahunan lebih dari Rp2.500.000.000 sampai dengan paling banyak Rp 50.000.000.000 (Agustina,T 2015).

Pengembangan UMKM berbasis digital merupakan alternatif menyelamatkan UMKM di masa pandemi Covid-19. Ranah dari kewirausahaan digital meliputi bisnis usaha yang memanfaatkan teknologi informasi. Kewirausahaan digital ini disampaikan dalam penelitian yang dilakukan oleh Arianto,B (2020) kewirausahaan digital merupakan bentuk bisnis yang memanfaatkan kecanggihan teknologi digital, baik proses hingga pemasaran produk. Segala usaha yang menjual produk secara online baik menggunakan website atau aplikasi termasuk dalam ranah kewirausahaan digital. Penggunaan aplikasi $e$-commerce dan pemanfaatan media sosial dalam pemasaran digital termasuk ranah kewirausahaan digital. Kemudahan dalam penggunaan media sosial bagi kewirausahaan digital disampaikan dalam penelitian Sudiyarti (2020) kewirausahaan online tidak menuntut pelaku usaha membuat aplikasi sendiri. Menumpang dari aplikasi yang sudah adapun bisa dan usaha sudah bisa dijalankan. Mekanisme kewirausahaan online sangat mudah dijalankan dan cepat dalam berproses.

Konsep dari kewirausahaan digital menawarkan solusi dan kemudahan dalam memperoleh barang dan jasa serta tidak memakan banyak biaya promosi maupun sewa tempat. Namun dalam pelaksanaan sistem kewirausahaan digital ini tidak hanya membutuhkan satu atau dua modal kemampuan di bidang teknologi saja, namun harus juga didukung dengan daya inovasi dan kreativitas berupa inovasi teknologi dalam balutan kreativitas dan pengetahuan yang dimiliki pelaku usaha. Artinya pemikiran ide kreatif sangat dibutuhkan dalam melaksanakan kewirausahaan digital. Ekosistem baru akan tercipta dalam UMKM dengan model kewirausahaan digital. Memunculkan inovasi baru UMKM dalam meningkatkan produktivitas dan kesejahteraan masyarakat pelaku usaha UMKM. Nuansa baru dalam kewirausahaan digital UMKM akan memotivasi pemanfaatan teknologi dalam jaringan pemasaran produk dan akan memperluas eksistensi UMKM di dunia digital.

Kewirausahaan digital dalam UMKM yang terjadi di masa pandemi ini sebagai upaya pemulihan ekonomi Indonesia. Kegiatan ekonomi melalui UMKM digitalisasi sebagai bentuk pemulihan ekonomi masyarakat di tengah pandemi yang memberikan dampak besar terhadap kelangsungan usaha yang dijalankan. Masa pandemi Covid-19 menuntut setiap pelaku usaha untuk berinovasi. Digitalisasi UMKM sebagai bentuk upaya pemerintah untuk membangkitkan kembali perekonomian yang terpuruk disebabkan oleh pandemi Covid-19 yang dalam hal ini UMKM sebagai sektor yang terdampak. Pemerintah memberikan anjuran kepada pelaku usaha UMKM untuk berinovasi mulai mengadopsi dan mengenal sistem digitalisasi dalam UMKM. Hal ini bermanfaat bagi kelangsungan usaha yang dijalankan mengingat kondisi saat ini pemasaran produk yang tidak dapat dilakukan dengan sistem pemasaran langsung namun sudah mengalami perubahan paradigma pemasaran yaitu menggunakan media digital dalam memperkenalkan, maupun menjual produk usaha kepada konsumen. Penghematan dari sisi biaya terasa dengan pemanfaatan UMKM digital ini serta efisiensi terhadap tenaga kerja. Efisiensi akan terasa dengan pemanfaatan kewirausahaan digital, baik efisiensi tenaga kerja, efisiensi sewa tempat, efisiensi produksi, efisiensi biaya promosi.

\section{Digital Marketing}




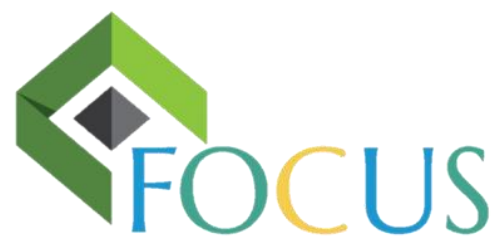

\section{orewOAacesss}

Melambatnya pertumbuhan ekonomi dimasa pandemi Covid-19 telah memberikan gagasan baru pelaku usaha dengan dukungan pemerintah untuk melakukan metode pemasaran produk dengan paradigma yang berbeda dengan sebelumnya. Melambatnya pertumbuhan dan perkembangan UMKM mengakibatkan rendahnya pertumbuhan ekonomi rakyat, turunnya daya beli masyarakat akibatnya masyarakat tidak mampu memenuhi kebutuhannya. Keberlanjutan UMKM yang bergantung pada laju perputaran barang, jasa, dan manusia mengalami keterbatasan pergerakan. Menghadapi hal ini pemerintah secara regulasi melakukan upaya dalam menjaga keberlangsungan usaha UMKM. Mengenai hal ini disampaikan dalam penelitian Marlinah,L (2020) pemerintah Indonesia melalui kementerian koperasi dan usaha kecil dan menengah mendukung penggunaan sistem perdagangan elektronik atau e-commerce sebagai solusi bagi koperasi dan pelaku usaha mikro kecil menengah (UMKM) dalam memasarkan produknya di tengah pandemi Covid-19.

E-commerce memiliki pengaruh besar bagi peningkatan kinerja pemasaran serta pendapatan pelaku usaha UMKM. Penerapan Pembatasan Sosial Berskala Besar (PSBB) yang dikeluarkan oleh pemerintah dengan PP Nomor 21 tahun 2020 dimaksudkan untuk membatasi pergerakan orang yang mengharuskan masyarakat untuk tidak keluar dari rumah selama tidak ada keperluan mendesak dengan berdiam diri di rumah. Pembatasan ini akan berdampak pada pelaku UMKM dalam menjalankan roda usahanya dikarenakan konsumen mengalami penurunan dalam berbelanja secara langsung. Hal ini dapat dimanfaatkan oleh pelaku usaha untuk membuka usaha online dengan berjualan melalui e-commerce. Metode ini merupakan metode pemasaran dengan menggunakan elektronik. Selain penggunaan $e$-commerce, pelaku dunia usaha juga dituntut untuk mampu mengkomunikasikan produk secara intensif melalui sistem pemasaran produk digital marketing. Pemanfaatan media sosial dalam menjangkau konsumen melalui sosial media dan meminimalisir biaya promosi dengan penerapan digital marketing dapat membantu pelaku usaha dalam memasarkan produk yang dimiliki juga dapat memperluas jangkauan pemasaran produk ke pelosok yang sebelumnya tidak terjangkau dikarenakan keterbatasan jarak, waktu, dan media komunikasi.

E-commerce merupakan proses penjualan produk secara elektronik yang dilakukan konsumen maupun dari perusahaan ke perusahaan melalui penggunaan elektronik. Penggunaan e-commerce ini akan mempermudah hubungan perusahaan atau pelaku usaha dengan pelanggan. Pesaing pun dapat dengan mudah. Dari jumlah itu mengadopsi pemasaran yang dilakukan pelaku usaha lain. E-commerce dapat dilakukan dengan penggunaan platform seperti Shopee, Tokopedia, Bukalapak, OLX, Gojek, Lazada, dls. Beberapa hasil penelitian menyampaikan hasil penelitiannya yang menyimpulkan ada pengaruh signifikan antara $e$-commerce terhadap peningkatan kinerja pemasaran dan pendapatan usaha. Penelitian yang dilakukan Hardilawati (2020) terdapat pengaruh yang positif dan signifikan antara pemasaran e-commerce dalam meningkatkan kinerja dan pendapatan UMKM. Manfaat penggunaan e-commerce disampaikan dalam penelitian yang dilakukan Kurniawan dalam Rosmadi,M (2021) dapat disimpulkan bahwa $e$-busines dan $e$-commerce sangat berguna dan bermanfaat baik bagi produsen yang memiliki produk maupun konsumen yang membutuhkan produk dengan cepat, tepat, dan sesuai dengan yang diharapkan. Penelitian Kala'lembung,A (2020) munculnya pasar e-commerce telah menciptakan peluang pasar yang luas. Meskipun pandemi Covid-19 sedang melanda, namun akses internet tetap bisa dimanfaatkan. Dunia e-commerce terbuka lebar untuk pelaku UMKM meningkatkan penjualannya. UMKM secara tidak langsung diajak mengubah cara bertransaksi mereka, yang awalnya secara offline maka di pandemi ini beralih ke secara online. E-commerce dipercaya dapat meningkatkan penjualan para pelaku ekonomi. Penggunaan media online dalam UMKM disampaikan dalam penelitian Pasaribu,R (2020) kementerian koperasi dan usaha kecil menengah (UKM) mencatat ada 64,1 juta pelaku UMKM di Indonesia pada semester pertama 2019. Dari jumlah itu sebanyak 63,3 juta atau 98,6 persen merupakan pelaku usaha mikro sisanya pelaku usaha menengah 1,2\% dan pelaku usaha kecil 0,09\%. Dari 64,2 juta pelaku UMKM itu baru13\% atau sekitar 8,3 juta UMKM diantaranya yang sudah memanfaatkan digitalisasi dalam menjalankan usahanya.

Penerapan digital marketing tentunya tidak semudah yang dibayangkan mengingat pelaku UMKM juga tersebar di pelosok desa. Banyak masyarakat dengan taraf pendidikan mereka yang rendah selaku pelaku usaha mengalami kesulitan ketika menerapkan pemasaran digital pada sosial media dikarenakan masih banyak masyarakat di pelosok yang masih kurang dan tidak familiar dengan platform yang biasa digunakan dalam $e$ commerce maupun digunakan dalam pemasaran digital. Hasil penelitian yang dilakukan oleh Andayani,I et al 
(2021) pelaku UMKM membutuhkan strategi dalam berhadapan dengan situasi pandemi Covid-19. Strategi yang dapat dilakukan dengan melakukan pemasaran online. Namun dalam pelaksanaannya pemasaran online sering dihadapkan dengan kendala pelaku UMKM yang belum memahami secara utuh cara pemasaran produk secara digital, serta publikasi produk di platform digital. Melihat hasil penelitian tersebut bisa kita pahami bahwa pengguna dalam hal ini pelaku usaha harus mampu dan memiliki keterampilan disertai pengetahuan dan pemahaman yang dimiliki dalam memunculkan daya kreativitas pemasaran produk menggunakan media digital. Beberapa teknis mungkin yang bisa digambarkan di sini bahwa pelaku usaha harus memiliki kemampuan daya kreativitas dalam mendeskripsikan dengan baik dan tepat untuk menggambarkan produk yang ditawarkan, memunculkan pesan positif kepada konsumen, menyusun konten semenarik mungkin. Penyusunan pesan dalam media digital perlu didukung bentuk poster, video serta penggunaan testimoni dari endoser. Setiap media digital yang digunakan memiliki gaya pesan penyampaian yang berbeda-beda. Kombinasi dari pengetahuan dan kreativitas dibutuhkan dalam penggunaan media digital. Selain penyusunan yang harus mampu dikemas semenarik mungkin, juga perlu pertimbangkan aktualisasi dari pesan, kemudian mudah diterima karena dikemas senatural mungkin dalam kemasan pesan yang unik, jelas, tidak menimbulkan makna ambigu, gampangnya pesan mudah dimengerti.

Penggunaan media digital membutuhkan pemahaman pengguna dalam pemilihan media yang tepat dan sinkron sesuai kebutuhan pemasarannya. Pelaku usaha harus memahami karakter dari konsumennya misalnya media digital apa yang digunakan untuk mengalokasikan iklan yang seperti apa juga. Media mana yang dipilih dan segmentasi pasar yang diajak interaksi juga kepada segmentasi pasar yang mana, serta model pesan yang bagaimana yang digunakan, hal ini perlu dicermati oleh pelaku usaha dalam menggunakan media digital supaya tepat sasaran dalam penggunaan dan tujuan yang diharapkan. Penggunaan pesan dalam pemasaran perlu pemilihan yang tepat, timing yang tepat, pemilihan bahasa juga mempertimbangkan khalayak segmentasi pasar, Perlu rancangan format yang tepat dalam proses pemasaran dengan media digital supaya pesan pemasaran efektif dan efisien. Hal ini senada dengan yang disampaikan dalam penelitian Pasaribu,R (2020) proses pembuatan pesan harus diperhatikan dengan baik. Tujuannya menarik konsumen untuk dapat menerima pesan dan memutuskan membeli dan harapannya dapat loyal dengan produk yang diluncurkan.

Kombinasi dari pengetahuan dan keterampilan pelaku usaha untuk menciptakan kreativitas dalam pemasaran digital sangat dibutuhkan saat ini. sebenarnya media digital dapat dijadikan alat utama yang dipilih elaku usaha untuk mengomunikasikan produk yang dimiliki kepada konsumen, bahkan hal ini bisa dilakukan sebelum pandemi Covid-19 berlangsung. Perubahan paradigma metode pemasaran ini memaksa pelaku usaha untuk mulai familiar dengan penggunaan media pemasaran digital yang dikemas dalam kreativitas model pemasaran untuk dapat dipahami dan diminati oleh konsumen dari promosi penjualan yang disampaikan. Hasil wawancara dengan beberapa pelaku usaha UMKM menyebutkan bahwa beberapa dari mereka menyampaikan bahwa pemasaran digital tidak selamanya efektif dan bagi beberapa pelaku usaha menyampaikan bahwa tidak menjamin produk yang dimiliki laku atau mampu meningkatkan daya beli konsumen. Beberapa pelaku usaha menyampaikan bahwa belum memanfaatkan media pemasaran digital secara optimal khususnya pelaku usaha yang berada di pelosok. Beberapa dari mereka lebih merasa efektivitas pemasaran lebih terasa dan mereka peroleh ketika melakukan komunikasi pemasaran secara tatap muka atau yang biasa dilakukan langsung berinteraksi dengan konsumen. Kondisi pandemi ini memaksa dan mengharuskan pelaku usaha untuk mulai membiasakan diri dengan penggunaan teknologi informasi melalui pemasaran digital dalam memasarkan produknya. beberapa pelaku usaha lain menyampaikan bahwa penggunaan pemasaran digital sangat membantu mereka dalam memasarkan produknya dan membutuhkan daya kreativitas yang baik dalam penyampaian pesan. Perubahan paradigma pemasaran ini memberikan nuansa dan pengalaman baru bagi pelaku usaha UMKM. Bagaimanapun di antara kendalanya, tentunya ada juga manfaat yang diperoleh dunia usaha di tengah terpuruknya perekonomian di masa pandemi Covid-19 melalui pemanfaatan media digital. Optimalisasi media online selama masa pandemi ini menjadi jalan keberuntungan dalam menyelamatkan kelanjutan dan keberlangsungan roda perekonomian rakyat melalui penyelamatan nasib UMKM.

Guna menyukseskan pemasaran menggunakan media digital di tengah masyarakat yang masih ada mengalami kesulitan untuk berdampingan dengan dunia teknologi informasi, maka di sini dibutuhkan peran dan 


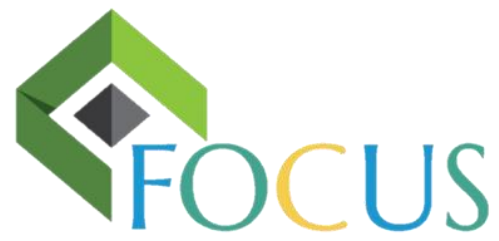

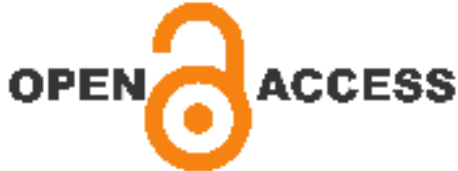

partisipasi pemerintah guna menggalakkan literasi digitalisasi dalam pemasaran bagi pelaku usaha UMKM supaya nantinya memiliki kebiasaan dan familiar dengan penggunaan media digital. Upaya literasi teknologi digital dalam pemasaran di masa pandemi ini sudah dijalankan oleh pemerintah baik berupa pendampingan, pelatihan kepada pelaku usaha UMKM maupun dukungan pemerintah dalam menyukseskan program digitalisasi UMKM. Menurut antaranews.com dalam Arianto,B (2020) menyebutkan bahwa Kementerian Komunikasi dan Informatika (Kominfo) baru meluncurkan Program Pelatihan UMKM digital. Berbagai program ini ditujukan untuk memberikan pendampingan bagi para pelaku UMKM agar dapat beralih ke platform digital dalam berbisnis. Hal ini didorong oleh data dari Kementerian Koordinator Bidang Kemaritiman dan Investasi yang mencatat dari 60 juta unit UMKM harapannya ada 30 juta UMKM yang dapat masuk ekosistem digital. Ini baru sekitar 11 juta hingga 12 juta UMKM yang berjualan di platform digital sehingga pemerintah menilai masih banyak yang perlu didorong untuk masuk berjualan secara digital dalam platform digital. Hal senada tentang pentingnya campur tangan pemerintah untuk mencapai pelaku usaha melek teknologi informasi dalam digital marketing menurut Kominfo.go.id dalam Arianto,B (2020) masih ada kesenjangan terhadap akses internet meskipun pengguna internet di Indonesia mencapai 73\% pada November 2020. Hal ini harus segera diselesaikan pemerintah dalam mendukung program digitalisasi UMKM. Perbaikan infrastruktur digital menjadi kunci utama dalam pengembangan UMKM, selain yang sudah didukung UU Cipta Kerja yang dinilai berpihak kepada UMKM. Pemerintah juga perlu terus menggalakkan dukungan terhadap urgensi infrastruktur digital dalam mendukung Program Gerakan Nasional bangga Buatan Indonesia untuk mendorong masyarakat lebih mencintai produk local. Melihat dari program yang sudah dijalankan oleh pemerintah untuk pelaku usaha melek teknologi informasi dalam pemasaran digital, di sini kita bisa memahami bahwa sudah saatnya pelaku UMKM mengadopsi penggunaan digital dalam pengembangan unit usahanya.

\section{Kreativitas dan Inovasi}

Kreativitas adalah kemampuan dalam menemukan gagasan dan penemuan baru dalam menghadapi masalah dan peluang. Kreativitas merupakan kunci keberhasilan. Siapa pun dapat berpikir kreatif. Kreativitas tidak diturunkan atau diwariskan namun kreativitas juga dapat dipelajari. Inovasi adalah kemampuan untuk menerapkan solusi kreatif terhadap masalah dan peluang untuk meningkatkan dan memperkaya kehidupan masyarakat (Agustina,T, 2015).

Situasi yang terjadi di lokasi penelitian tepatnya di lokasi makam religi Syaichona Cholil. Kawasan wisata religi ini merupakan lokasi kawasan wisata yang menjadi icon kota Bangkalan. Sejak peraturan PSBB diterapkan oleh pemerintah melalui Peraturan Pemerintah No.21 Tahun 2020 tepatnya tanggal 31 Maret 2020, perlahan namun pasti peraturan PSBB ini memberikan dampak pada geliat UMKM di lokasi kawasan wisata religi makam Syaichona Cholil ini. Kita kenal wisata ini sebagai icon kota Bangkalan dan rasanya tidak lengkap jika berkunjung ke kota Bangkalan tidak mengunjungi kawasan wisata ini. Lokasi ini menjadi sentra UMKM dan rujukan pusat oleh-oleh para wisatawan seperti makanan dan kerajinan (craft) unik khas Bangkalan. Terdapat pula beberapa distro yang menjual kaos dengan icon bernuansa Madura dan nuansa wisata religi Syaichona Cholil. Terdapat pula minimarket dan minicafe yang melengkapi lokasi wisata religi ini. Sejak PSBB diberlakukan san sampai saat ini pandemi belum usai, kondisi wisata religi ini tidak serame sebelumnya. Terjadi penurunan intensitas pengunjung sehingga berdampak pada UMKM yang menjual beberapa kerajinan dan khas kota Bangkalan yang berada di sekitar lokasi tersebut. Kondisi yang berbeda dari sebelumnya ini kemudian menjadi situasi yang harus dihadapi oleh pelaku usaha di sekitarnya yang berdampak pada penurunan pendapatan dari sebelumnya. Beberapa penjual menutup rukonya, namun ada beberapa yang tetap buka dengan kondisi ruko yang sedikit pembeli (sepi). Mayoritas pedagang UMKM di kawasan tersebut menggunakan sistem pemasaran direct selling (pemasaran secara langsung), sehingga penurunan intensitas pembeli berdampak pada pendapatan penjualan mereka dikarenakan pandemi Covid-19 dengan kebijakan percepatan penanganan abah virus ini yang dikeluarkan pemerintah melalui kebijakan PSBB yang diberlakukan.

Situasi di atas menjadi suatu kondisi di mana pelaku UMKM diharapkan untuk mampu bertransformasi sistem pemasaran yang awalnya direct selling harus mulai berubah haluan menjadi sistem pemasaran dengan metode pemasaran online. Hanya beberapa pedagang yang pelakunya kaum millenial yang berada di lokasi wisata 
religi Syaichona Cholil yang menerapkan pemasaran dengan media digital selebihnya mayoritas masih menggunakan sistem pemasaran konvensional dengan bertatap muka dengan pembeli. Sepinya intensitas pembeli memberikan dampak yang sangat besar terhadap keberlanjutan usaha yang sudah bertahun-tahun dijalankan dan imbasnya berdampak pada pendapatan usahanya.

Berbicara kreativitas dan inovasi, sepertinya sudah menjadi hal mutlak yang harus dijalankan dan diadopsi oleh para pelaku usaha dalam menyikapi situasi dan kondisi saat ini sebagai imbas dari adanya pandemi ini. Kreativitas yang memunculkan ide dan gagasan baru dalam nuansa kemampuan personal dalam menerapkan ide kreatif tersebut dalam inovasi sangat membantu dan dapat menumbuhkan kembali geliat UMKM yang terdampak oleh pandemi ini. Kreativitas dan inovasi dapat diterapkan oleh pelaku UMKM mulai dari peningkatan kualitas dan atribut produk bisa dilakukan dengan peningkatan mutu, desain produk, ketahanan dan desain kemasan produk (packing). Kreativitas dan inovasi dalam peningkatan kualitas dan atribut produk ini disampaikan Kaihatu dalam Rofiq,M (2020) meskipun terdapat pesaing yang memiliki produk yang sama, dengan kemasan yang berbeda menjadi faktor dalam intensitas kompetisi antar pelaku usaha. Ini menjadi faktor penting dalam pendeskripsian secara visual melalui nama, logo, merek produk, warna, dan elemen desain lainnya.

Inovasi sangat memiliki keterkaitan dalam kewirausahaan. Antara kewirausahaan, kreativitas, dan inovasi saling bersinergis dalam keterlaksanaannya. Wirausaha erat kaitannya dengan kemunculan ide atau penemuan serta inovasi yang berupa keterlaksanaan dari penemuan maupun ide dalam bentuk sesuatu yang baru yang belum pernah ada sebelumnya. Agustina,T (2015) wirausaha bukanlah hanya sebagai penemuan (invention) semata, tapi juga sebuah penambahan nilai (inovasi) dari temuan yang sudah ada. Wirausaha memiliki keahlian khusus dalam melakukan inovasi karena mereka lebih mengenal apa yang dibutuhkan oleh pasar atau masyarakat. Keterkaitan antara wirausaha dan inovasi juga disampaikan dalam penelitian yang dilakukan Sudiyarti (2020) kewirausahaan dan inovasi sebagai respon pelaku usaha untuk menyikapi perubahan dalam dunia $e$-commerce sebagai bentuk transformasi sistem pemasaran konvensional.

\section{PENUTUP}

Berdasarkan hasil penelitian dan temuan dari penelitian ini maka dapat diberikan kesimpulan bahwa perlu adanya transformasi kewirausahaan di tengah pandemi Covid-19 dari kewirausahaan konvensional menuju kewirausahaan digital. Pemasaran dengan media digital menjadi hal baru yang perlu diadopsi oleh pelaku usaha UMKM dalam kelangsungan usaha di tengah pandemi Covid-19. Ide kreatif dan penemuan (inovasi) menjadi komponen penting yang mengikuti pelaku usaha dalam menjalankan wirausaha digital.

Penelitian ini memberikan gambaran pelaku usaha UMKM di tengah pandemi Covid-19 dalam tantangan untuk bertahan didukung adanya digitalisasi yang bisa dimanfaatkan sebagai media untuk bertahan. Saran yang disampaikan dari hasil temuan penelitian ini sebagai berikut:

1. Pelaku usaha di tengah pandemi perlu melek teknologi untuk kemudahan dalam adopsi pemasaran digital demi kelangsungan usaha yang dijalankan

2. Dukungan pemerintah sebagai pendorong bagi pelaku usaha untuk familiar dengan teknologi digital dalam pemasaran online.

3. Pelaku UMKM membutuhkan pelatihan, pendampingan, dan dukungan pemerintah melalui pihak terkait dalam menyukseskan digitalisasi UMKM.

4. Sebagai referensi peneliti berikutnya.

\section{DAFTAR PUSTAKA}

Agustina, T. S. (2015). KEWIRAUSAHAAN: Teori dan Penerapan pada Wirausaha dan UKM di Indonesia. Jakarta: Mitra Wacana Media.

Andayani, I., Roesminingsih, M. V., \& Yulianingsih, W. (2021). Strategi Pemberdayaan Masyarakat Pelaku UMKM Di Masa Pandemi Covid-19. Jurnal Pendidikan Nonformal, 16(1), 12-20.

Arianto, B. (2020). Pengembangan UMKM Digital di Masa Pandemi Covid-19. ATRABIS: Jurnal Administrasi 


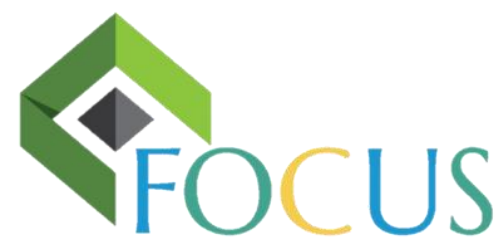

orewOAacesss

Bisnis (e-Journal), 6(2), 233-247.

Arifqi, M. M., \& Junaedi, D. (2021). Pemulihan Perekonomian Indonesia Melalui Digitalisasi UMKM Berbasis Syariah di Masa Pandemi Covid-19. Al-Kharaj: Jurnal Ekonomi, Keuangan \& Bisnis Syariah, 3(2), 192205.

Dwijayanti, A., \& Pramesti, P. (2021). Pemanfaatan Strategi Pemasaran Digital menggunakan E-Commerce dalam mempertahankan Bisnis UMKM Pempek4Beradek di masa Pandemi Covid-19. IKRA-ITH ABDIMAS, 4(2), $68-73$.

Kala'lembang, A. (2020). Adopsi E-Commerce Dalam Mendukung Perkembangan Usaha Mikro Kecil Dan Menengah (UMKM) Di Masa Pandemi Covid-19. CAPITAL: Jurnal Ekonomi Dan Manajemen, 4(1), 5465 .

Kristiyanti, M. (2012). Peran strategis usaha kecil menengah (UKM) dalam pembangunan nasional. Majalah Ilmiah Informatika, 3(1), 63-89.

Marlinah, L. (2020). Peluang dan Tantangan UMKM dalam Upaya Memperkuat Perekonomian Nasional Tahun 2020 ditengah Pandemi Covid-19. Jurnal Ekonomi, 22(2).

Nalini, S. N. L. (2021). Dampak Dampak Covid-19 terhadap Usaha MIkro, Kecil dan Menengah. Jesya (Jurnal Ekonomi Dan Ekonomi Syariah), 4(1), 662-669.

Pakpahan, A. (n.d.). Covid-19 dan Implikasi Bagi Usaha Mikro, Kecil, dan Menengah. Fakultas Ilmu Sosial Dan Ilmu Politik, Universitas Katolik Parahyangan.

Pasaribu, R. (2021). Optimalisasi media online sebagai solusi promosi pemasaran umkm di semarang pada masa pandemi Covid-19. Jurnal Komunikasi Dan Media, 1(1), 33-44.

Rofiq, M. A., Nawawi, M. A. A., Syafitri, R. I., Ektiarnanti, R., \& Maenadi, D. (2020). TRANSFORMASI BISNIS KREATIF MICRO ENTERPRENEUR DALAM MEMPERTAHANKAN OMSET DI MASA COVID-19. Seminar Nasional Manajemen, Ekonomi Dan Akuntansi, 5(1), 489-497.

Rosita, R. (2020). Pengaruh pandemi Covid-19 terhadap UMKM di Indonesia. Jurnal Lentera Bisnis, 9(2), 109120.

Rosmadi, M. L. N. (2021). Penerapan Strategi Bisnis di Masa Pandemi Covid-19. IKRA-ITH EKONOMIKA, 4(1), $122-127$.

Sarfiah, S. N., Atmaja, H. E., \& Verawati, D. M. (2019). UMKM sebagai pilar membangun ekonomi bangsa. Jurnal REP (Riset Ekonomi Pembangunan), 4(2), 137-146.

Sudiyarti, S. (2020). KREATIVITAS DAN INOVASI USAHA MELENIAL DUKUNG PEREKONOMIAN NEGARA DITENGAH PANDEMI COVID-19. DEDIKASI, 21(2), 95-105. 